\title{
Taking care of you and care for others: an analysis of the activity of the work of technical and nursing assistants of a psychiatric institution for children and adolescents
}

\author{
Davidson Passos Mendes ${ }^{\mathrm{a},{ }^{*}}$, Geraldo Fabiano de Souza Moraes ${ }^{\mathrm{b}}$ and Juliana Cristina de Lima Mendes ${ }^{\mathrm{c}}$ \\ ${ }^{a}$ Federal University of Itajubá - Campus Itabira, Itabira, Minas Gerais, Brazil \\ ${ }^{\mathrm{b}}$ Federal University of Itajubá - Campus Itabira, Itabira, Minas Gerais, Brazil. E-mail: \\ geraldofsmoraes@gmail.com \\ ${ }^{c}$ Nurse of the Evangelical Hospital - Belo Horizonte, Minas Gerais, Brazil.Email: jucris_lima@yahoo.com.br
}

\begin{abstract}
Our objective in this study, the analysis of potential fields of risk management in nursing work in psychiatric care to adolescents and children, while settings that go from the relationship between technical and organizational determinants of work activity and the skills of operators. It was established focus on the work process of the TECHNICAL AND NURSING ASSISTANTS to seek for response elements in an attempt to understand the health-disease process experienced by these workers. It was used for analysis and data collection, through the method of Ergonomic Work Analysis (EWA), fifteen workers of nursing staff - T\&NA, between effectives and contractors, and the strategies of action and regulation of these workers in relation to the interface that they deal with. The results show that the workers are exposed to all charges in an intense and specific way, causing physical and mental wear, as it approaches the psychological distress, exposure to the psychic pressure, not only through contact with the object of work, but the complexity of these relationships that are involved in nursing staff.
\end{abstract}

Keywords: ergonomics, nursing, occupational risk, work process

\section{Introduction}

The aim of this paper is to demonstrate ways of execution of the nursing activity (auxiliary and technical), in a psychiatric hospital for adolescents and children, revealing the accidental factors or processes wear and the coping strategies used.

Hospitals differ from other institutions mainly by their complexity and uniqueness of the services that must meet the needs of individual clients (patients). Moreover, the peculiarities of labor relations that are put into practice in the hospital, directly affect the morale of the teams, which can be seen by the low levels of satisfaction and employee motivation and high levels of absenteeism and turnover [15,31].

The division of labor in the hospital reproduces the evolution and division of labor in the capitalist mode of production, being preserved, however, charitable and religious characteristics. The hospital bears the burden of pain, illness and death since its inception [29].

\footnotetext{
*Corresponding author. Rua Um s/n ${ }^{\circ}$ Distrito Industrial. Itabira. Minas Gerais. Brasil. CEP 35903-081.
}

E-mail: davidsonpmendes@gmail.com 
The work process in a hospital is fragmented, and reproduces the characteristics of the organization of industrial labor, which sometimes produces workers committed, and others hopeless. It frequently repeats the logic of the "Taylorized" work ' which is often hidden by the discourse of 'teamwork' [4,5].

The incorporation of new technologies does not mean, in this sector, "the relief of human toil," in contrast, the sector is essentially a labor-intensive [28]. A growing number of communications related to mental disorders, use of medicines and suicides of the nursing workers [21].

It is found in the literature few studies that address worker health nursing (TE) that acts in psychiatric care. Among the national studies, most depict situations like dealing with suicide and permanent state of alert in the daily work that can compromise the mental health worker $[8,15]$.

This reality has been built historically guided in how individuals with mental problems, has been taken care of by society, being deleted and reclusive [1]. This resonates to this day, implying that workers take on the responsibility of care [28].

In practice nursing care workers are exposed to risks arising from the development of direct and indirect care activities, directly patients care, and organizing, cleaning and disinfecting materials, equipment and environment $[15,25]$.

The activities performed by nursing staff present situations that require decision making and organization of tasks resulting in workloads that can be reduced through adequate professional training [2]. This situation requires the need for a continuous process of adaptation between work and worker to that the assistance provided to the client be of a good quality at the same time enables the worker carries out its activities without prejudice to their physical and mental health $[3,15]$.

In search of elements in response to the questions raised, result of a demand previously made, it was established focus on the work activity of assistant and technical nursing in a psychiatric institution, linked to a complex mental health, in an attempt to establish elements for better systems to prevent and control risks.

\section{Methodology}

The methodological approach was based on the Ergonomic Analysis of Work - EAW [22]. It is a descriptive qualitative method of action of ergonomics, defined as the description of work activities or of the workers from three steps. The first contained the observation of activity, followed by a second stage consisting of a semi-structured interview with the working population in focus. This description is validated from a third essential step of the methodology, which is the self-confrontation interview (SCE) of workers with the facts observed by researchers $[22,27]$. Through interviews, the perception of workers (assistants and technicians) was brought by images and representations used by them to express their experiences of work / pain / pleasure in nursing activity. It attempts to unravel the speech utterances, while a structure of representation that leads to subjectivity and reports on the organizational characteristics of this work, as well as the regulatory processes put in place.

\subsection{Hypothesis}

The illness of the population of nursing (assistants and technicians), is due to the diversity of employment relationships existing in the institution, coupled with the complexity of the object (mental patient), nursing supervision occur at a distance, not construction partnerships at work, that reduce the possibility of regulation of the working population. Besides the absence of the collective work, the in definition of activity and frequent variability of incidents expand the workload.

\section{Results}

\subsection{General characteristics}

The hospital in question is a hospital unit of a state foundation, which is considered the largest network of public hospitals in Latin America: has 23 healthcare units, of which 14 are located in the capital and 9 in the inside state, home to 13000 operating beds distributed among hospitals, day hospital, drugs abuse Care Services, Emergency Room, an administrative unit and a unit transplants [18].

It is configured at this institution, a point of interface and knowledge aimed at the confluence of the psychical field of adolescence and childhood, creating spaces for interaction between the areas of health, education and culture. The institutional path is guided by the exercise of care activities geared towards young children, regardless of privileging certain theoretical trends in some specific moments of its history [18]. It provides secondary and tertiary 
care, specialist outpatient and emergency, the users of the Unified Health System (SUS).

Assistance involves various groups of professionals working in the mental health of adolescence and childhood, such as psychiatry, pediatrics, neurology, social work, psychology, occupational therapy, speech therapy, physical therapy and pedagogy $[6,9]$.

The institutional design reorganizes - according to guidelines recommended by the Psychiatric Reform the provision of clinical services specific to childhood and adolescence. This reorganization ongoing in the clinical service is based on close observation of demand flow, considering the arrival, stay and departure of users [18].

The emergency department of this hospital is composed of mental health care, emergency care and systematic assessment of psychiatric nursing, when the user indicated to remain in the unit for more than 24 hours [17].

The secondary outpatient care, specialized mental health of children and adolescents, linked to local and state health care network, receives secondary demands directed primarily by healthcare institutions (Health Departments of cities in the state, health centers and the capital metropolitan region, CAP'S CERSAM's), educational (schools) or judicial authorities. Besides the availability of the work of professional groups with training in the care of children and adolescents, the unit offers to their users, pharmacy supply of medication for internal and external service and electroencephalography (EEG). Besides the provision of public mental health care, the hospital also develops training activities, providing medical residency in operation for 22 years, accredited by the Ministry of Education, focused on specialization in Child and Adolescent Psychiatry.

\subsection{Operative procedures of social actors}

The specific duties of the Technical and Nursing Assistants are: (Table 1) [18]:

- Perform comprehensive nursing care to patients under the supervision of nurses, integrating multidisciplinary care teams, seeking fulfillment of transdisciplinarity and technical protocols of the shares;
- Perform treatments prescribed in the healthcare units under the supervision of nurses, following institutional rules and care protocols and biosafety;

- Perform clinical nursing actions related to the functions of nursing assistants and technicians.

\subsection{Work process: the object and the working envi- ronment in nursing}

In the process of work, it is noted that the nature of the object (mental patient) is characterized as children and adolescents of both sexes, socially marginalized and institutionalized. There are patients with mental disorders typical, drug users, under court order, and a mixture of everything. The link to that object is formed by denied citizenship, sexuality and heightened danger.

The knowledge is in the daily work and know-how. Often the methods and techniques are performed in a mode non-therapeutic by diversity of the work object of the T\&NA (TECHNICAL AND NURSING ASSISTANTS). In the organization and division of labor, it realizes how much T\&NA have a critical view of the staffing and the need for criteria to adopted a more balanced proportionality between the number of patients assigned to each worker. The diversity of employment relationships leads to feelings of abandonment of the contracted in relation to labor rights. The effective staff has a greater adjustment range, often next to the hierarchical disobedience, creating conflicts, mainly with the immediate superior. The insertion in the labor market occurs, most often because of unemployment and not by choice. Supervision of nursing occurs at a distance, making it difficult to share knowledge, experiences, increasing the cognitive load (decision making) mainly.

The multidisciplinary relationships occur both constructive and destructive way. The interfaces mentioned above, more conflict, are among the own T\&NA (34.0\%) and T\&NA and nurses (23.8\%). However, it is observed that a large number of professionals in the rationalized responses, probably due to fear of punishment and did not answer this question $(40.0 \%)$. The behavior of some patients hypersexualized acts as enhancer of psychic workload. 
Table I

Professional Nursing - Auxiliary and Technicians

\begin{tabular}{|c|c|c|}
\hline \multicolumn{3}{|c|}{$\begin{array}{c}\text { CEPAI - Psychiatry } \\
\text { Supervisor of Nursing: } 1 \\
\text { Technical Reference: } 1 \\
\text { Assistants and nursing technicians: } 19\end{array}$} \\
\hline \multicolumn{3}{|c|}{$\begin{array}{c}\text { Assistants and nursing technicians } \\
1 \text { - Contract administrative head }\end{array}$} \\
\hline Female & 0 day / 2 night (2) & average age: 46 years \\
\hline Male & 3 day / 2 night (5) & average age: 46 years \\
\hline Total & 9 & \\
\hline \multicolumn{3}{|c|}{$\begin{array}{c}\text { Assistants and nursing technicians } \\
\text { Average time in CEPA }\end{array}$} \\
\hline Female & 3 day / 6 night (9) & average age: 50 years \\
\hline Male & 2 day / 1 night (3) & average age: 54 years \\
\hline Total & 12 & \\
\hline \multicolumn{3}{|c|}{ Average time in CEPAI: $16-20$ years } \\
\hline
\end{tabular}

Source: Institutional Data, $2008^{[18]}$

\section{Discussion}

The phenomenon of diseasing at work is coming from concrete ways of working in specific contexts of production [13]. The analysis of situation of work made by the ergonomics of the activity and ergology considers especially the distance between the requirements of tasks to be performed and the real work [10,27].

However, this relationship between the activity of human labor and the production can't be understood as a deterministic relationship. With regard to human ontogeny, the midst does not act directly on the biological order [7]. Health and Disease are realities constructed from a complex interaction between the concreteness of the human condition and the development of senses. This will require a debate between the normativity of life and social normativity, meaning that the relationships between each man and his milieu mobilize itself a complex system of values underlying their regulatory activity. Life is not indifferent to their own conditions, instead, to live is to position yourself [27].

The view of human activity is at the heart of the ergonomic approach [33]. The analysis of the work that evoke here are based, necessarily, the relationship between values, knowledge and competence to act, set in specific concrete situations of work, which requires bring out the experience of working. This position creates consequences for the production of knowledge on human labor, and especially in the field of health and work relationships. The human experience at work constitutes through of the ongoing self-management, condition to act in competence in productive situations. This presupposes that the act of working is not restricted to using a straight of men and women by the managers of production systems, but is also an experience of oneself, a relationship with its own history.

"The management, as a real human problem, is everywhere where there is variability, history, where it is necessary to account for something without being able to resort to stereotypical proceedings. All management involves choices, arbitrates, a ranking of actions and goals, therefore, values in the name of which these decisions are formulated" [33].

In the cases analyzed in this study there is no way to make a denial of subjectivity. In all cases, it is an appeal to human activity located and confronted the historicity of the events, incorporating special skills, able to handle the unique, the unexpected and atypical facts, with the object of work the psychiatric patient, child and adolescents, with their difficulties with aggression (and self hetero-aggressiveness), exacerbated sexuality and interfaces: doctor, patient, nurses and patients' relatives.

Worker satisfaction and personalized attention to the patient are the hospitals main goals [26,30]. However, many institutions are extremely bureaucratic and management of nursing do not have effective participation in the formulation of institutional plans, worsening the situation of nursing workers, favoring the heavy workload, and in turn triggering the risk for illness [27].

In recent years, absenteeism in nursing in hospitals has been a source of study and concern of many administrators, since it triggers both an organizational problems as primarily economic in nature, where it is 
estimated that at least $35 \%$ of working days lost each year are for psychological reasons $[19,26,27,30]$.

The T\&NA describe the nature of the object of working, and concepts close to those that society has on the mentally ill. As verbalized by a nursing workers, "Working with people is very difficult psychiatric, we have to be very patient and I already sold out long ago. Here is a mix of everything: psychiatric patients, drug users, drug dealers. "

The nature of the object of nursing work is therefore distinct. The T\&NA reveal a change in the profile of the mentally ill during the last decade, "work for a long time in hospital and had not drugged. The drugs came from and greatly increased our work. This is no place to treat drug addict, drug dealer. "

There are psychiatric patients, drug addicts, prisoners under State supervision and a mixture of it all. The diversity of the object leads to different ways of dealing with this interface, which causes insecurity. Fact commonly verbalized in conflict situations: "here is on fire today, only struggle. If I were you I would not be here long time. You see that girl there, cute, yeah. She's here for drug trafficking, prostitution and black magic, including murder".

The link is established with the object of work by the danger, denied citizenship, sexuality exacerbated attributed to the psychiatric patient and to direct contact with the chemically dependent.

The issue of sexuality exacerbated is a strong risk factor. The fact that boys and girls being together acts as enhancer of the workload, as expressed by one worker:

"You know one thing that does not exist anywhere, is to mix girls and women. These are teenagers with hormones awake and then have sex right here, and it is very. Then we get mad because you have to open the gate, answering the phone, giving medications, separate fight, have to go take a shower, watching the cricket and is not to have sex here".

The possibility of dealing with the unpredictable, in particular, physical abuse and 12-hour days of continuous work, leaves T\&NA in a state of permanent alert. The T\&NA feel scared by the possibility of being physically assaulted and threats of physical abuse made by patients. During working hours, are exposed to objects such as knives, pieces of wood, 'Chux' (sharp instrument made with brush or chair leg). Physical aggression manifested by kicking, punching and attempted strangulation. Knowledge is characterized by knowledge of T\&NA about their daily work, often established by a know-how, with little technical and scientific knowledge. The technique, in order to determine the actual limit of the social behavior of the patient, should be used as action to contain impulses, limit the other. As verbalized: "Stay outside the gate because we will prepare the medication to that guy who came in and we will hold him in strength. Tomorrow, when you get back will be more relaxed."

According Lucchese [24] there is a mismatch between teaching and practice of mental health nursing, in which the traditional educational practices no longer support efforts to meet contemporary needs. The nursing school has been built on a work object (patient) who is patient, bedridden and dependent. In mental health the patient is standing in a position of confrontation with the working population.

The T\&NA pointed the issue of employment like a matter of conflict. "The effectives can't come to work, it's okay. If we do not come, we are on the street. We work more, earn less. We are much more charged". Also voiced: "The contracted can't get sick, you will lose time off, you lose productivity. We work the same thing and still stays out of everything". According to T\&NA contracted, the contract is a weak link, it does not guarantee motivation at work. Regardless of being hired or effective, it realizes how intense is the workload for both links. Decision-making power of workers is small, depending on the supervision of nursing and other sectors and their possibilities for action are dependent on the operating rules of the institution. Have multiple tasks, expressed as:

"We have to look at patient reception and leave here only two employees to have 10 patients or 23 as it happened, we stay with only two here. And so: some others are covering up, because I have sinned often sexual relationship between them, since I was here alone with 13 patients to medicate, bathe, look not to fight, to lunch, open door, answering the phone, this is so, we do it all, is security, psychologist, secretary, sometimes even a doctor. Here is who makes the decision to us. The head nurse appears when she wants, here there is no supervision. And when we complain, they say we only see the negatives".

The multidisciplinary relationships established with other workers are manifested through positive and negative feelings [12]. Negative feelings are expressed by fault, by episodes of patient aggression by derogatory comments, generating feelings of discouragement, weariness and disgust, they demonstrate the lack of recognition for their work. Exposure to long working hours, the precariousness of labor relations, wage depreciation, the serious deficiencies in working conditions, as well as trigger the physical and emotional feelings that show workers with self- 
esteem down [14]. One should mention also the verbalizations about the lack of time, lack of time for yourself, for the exercise of subjectivity, leisure, the various forms of learning and their own self-care, particularly with health. The positives are revealed in the construction of horizontal, working partnerships, collectives working in a professional helps the other, share their expertise and thereby reduces the workload, increasing regulation, thus minimizing the risk of disease $[11,14,16]$.

Specifically, a psychiatric hospital for children and adolescents should take into consideration also the family, which helps in the therapeutic relationship, but often acts as intensifying the workload of T\&NA. As quoted by Pagliari [30], "family presence during hospitalization of children is essential for the nursing staff because it is the spokesman of the child, represents your feelings, attitudes ...". For T\&NA the entrance of the hospital changed the family in daily work, since the family was placed in the care established in the organizational structure of the hospital and had to conform to the norms of the institution. This process is permeated with moments of tranquility, but also conflict. It is the mediation of conflicts arising stressors in the work process.

The T\&NA exposure to workloads was perceived by them as physical and mental. The physical stress is reported as back problems, although nonspecific pain, are felt by the workers themselves and associate with the working day. The pain is felt by patients, and it often can't be associated with the period or situation that provoked them. Many pains are associated with physical aggression.

In addition to the wear processes that become visible, others not visible, are also experienced, that 'mark' deeply T\&NA as the mental strain. Dissatisfaction and discouragement for his work generates discomfort. Discouragement sense can be added to the state of tiredness or fatigue, becoming an important factor in mental strain. Fact verbalized:

"I do not come even a little motivated to work. Have you had a patient here that I did not answer it for anything. The aggression it was so great to me that I could not stand looking at his face. If he asked me something I did not, I just took medication for it. Not food I served. I left the counter and he picked up. Sometimes he would take food from the trash because he has a great physique and a 'takeaway' was not enough and I called his attention and he just needed to attack me, so I do not even look at him. Today, thank God he went to another hospital".
The complexity of these actions point to the dialectic of construction of defensive systems. The same object that makes you suffer is also resisting. The organization of work triggers adaptive psychological mechanisms.

According to the knowledge that can be observed in the presence of the contingencies of adaptive activity for situations in which the working population amounts to horizontal and thus mitigates the effect of workload on their working condition. The group most competent established regulatory strategies [23].

All these statements support the fact that the misfits in the work leading to a state indicative of disorder. The work should be aimed at the development of human potential, promoting cognitive and intellectual ties. The professional should not be a victim of its work and, yes, an essential tool for this task, with feelings, values and qualities essential to the full performance of their role [32,34].

\section{Conclusion}

The EAW did not intend to condemn or defend the position or view of the nursing team. However, it is an attempt to understand the attitude and behavior of these professionals face the conflicts experienced in their day-to-day with an agent to take care of your child and adolescent psychiatrist.

This study led us to understand that the work of professional T\&NA goes beyond the "technical skill" and is replaced by another role in a different scenario. These categories need to be participatory social subjects, critical, innovative processors and embedded in a society that is also changing, even though sometimes slowly.

Considering the health-disease process category, the T\&NA are exposed to all workloads, powered by the mental burden. The exhibition raises the wear process is characterized in that physical and mental. The enhancement of the mental burden also leads to the process of intense mental strain than physical. The work is very important because it stands out as something that complements and gives meaning to life, beyond compliance requirements, be they emotional or economic. However, if it is devoid of meaning, without social support, unrecognized or that would constitute a source of threat to physical and / or psychological, can trigger dissatisfaction leading to psychological distress.

Personal fulfillment comes as a factor value of work, meaning that the work should provide satisfaction / pleasure, an aspect that is considered inherent 
to the act of producing. It is attributed to the meaning of the work function to generate success, professional achievement, personal growth, intellectual challenges, responsibility and satisfaction when contacting the contents of the task. Therefore, to be meaningful there must be an attempt to combine productivity and working conditions, finding a correlation between physical and psychosocial needs of workers to the methods, processes and tools used by them. We should look for conditions that can implement regulations to provide broader, horizontal work and thereby minimize the risk of illness.

\section{References}

[1] M. Alves, S.C. Gogoy and D.M. Santana, Motivos de licenças médicas em um hospital de urgência-emergência, Revista Brasileira de Enfermagem, 59 (2006), 195-200.

[2] A. C. Andrade, A enfermagem não é mais um profissão submissa. Revista Brasileira de Enfermagem, 60 (2007): 9698.

[3] M.L. Anselmo, G.G. Duarte and E.L.S. Angerami, "Sobrevivência" no emprego dos trabalhadores de enfermagem em uma instituição hospitalar pública. Revista Latino-americana de Enfermagem, (2001), 13-8.

[4] R. Antunes, Adeus ao trabalho? Ensaios sobre as metamorfoses e a centralidade do mundo do trabalho, (6th ed), São Paulo: Cortez Editora, 1999.

[5] Z. Bauman, Modernidade líquida. Rio de Janeiro, Jorge Zahar, 2001.

[6] A.G. Bernardes and N. Guareschi, Trabalhadores da saúde mental: cuidados de si e formas de subjetivação, Psicologia USP, 15 (2004), 81-101.

[7] G. Canguilhem, Le normal et le pathologique. Paris: PUF, 1966.

[8] M.B. Carvalho and V.E. Felli, O trabalho de enfermagem psiquiátrica e os problemas de saúde dos trabalhadores. Revista Latino-americana de Enfermagem, 14 (2006), 61-69.

[9] COFFITO (Conselho Federal de Fisioterapia e Terapia Ocupacional). Resolução $n^{\circ} 259$ de 18 de dezembro de 2003, Brasil, 2003.

[10]F. Daniellou, Le statut de la pratique et des connaissances dans l'intervention ergonomique de conception, tese de livredocência - Université de Toulosse, Le Mirail, Toulosse, 1992.

[11]E.H. Echternacht, Alguns elementos para a reflexão sobre as relações entre Saúde e Trabalho no Brasil. Revista Brasileira de Medicina do Trabalho, 2 (2004), 85-89.

[12] E.H. Echternacht, Sobre a carga de trabalho. Belo Horizonte: Escola de Engenharia da UFMG, 12 f. Mimeografado, 2002

[13]E.H. Echternacht, Atividade humana e gestão da saúde no trabalho: Elementos para a reflexão a partir da abordagem ergológica. Laboreal, 4 (2008), 46-55.

[14]A.C. Faria and et al, Absenteísmo por transtornos mentais na enfermagem no período de 1995 a 2004. Arqu Ciência Saúde, 12 (2005), 14-20.

[15]J.D. Fernandes and et al, Saúde mental e trabalho feminino: imagens e representações de enfermeiras. Revista Latinoamericana de enfermagem, 10 (2002), 199-206.

[16] S.M. Fernandes and et al, Estresse ocupacional e o mundo do trabalho atual: repercussões na vida cotidiana das enfermeiras. Revista Eletrônica de Enfermagem, 10 (2008), 414-427.
[17]FHEMIG - Fundação Hospitalar de Minas Gerais. Revista de Psiquiatria \& Psicanálise: crianças \& adolescentes, 7 (2007).

[18]FHEMIG - Fundação Hospitalar de Minas Gerais. Dados internos, outubro, 2008.

[19]J. Filho, Saúde que se esgota: remuneração flexível $e$ prescrição no trabalho. Anais do XXVI ENEGEP, Fortaleza, Ceará, 2006.

[20]J.L França, A.C. Vasconcellos, Manual para normalização de publicações técnico-cientificas. (7th ed). Belo Horizonte: UFMG, 2004.

[21]B.P. Gomes, Bárbara Pereira. Contributos da formação para o desenvolvimento de competências na área de enfermagem de reabilitação. Texto contexto-enferm, 15 (2006), 193-204.

[22]F. Guérin and et al, Compreender o trabalho para transformálo: a prática da ergonomia. São Paulo: USP, Fundação Vanzolini, Edgard Blücher, 2005.

[23] A.C. Laurell and M. Noriega, Processo de Produção e Saúde. Trabalho e desgaste operário. Hucitec, 1989.

[24]R. Lucchese, A enfermagem psiquiátrica e saúde mental: a necessária constituição de competências na formação e na prática do enfermeiro. Revista Eletrônica de Enfermagem, 9 (2007), 883-885.

[25] M.H.P. Marziale and C.M. Rodrigues, A produção científica sobre os acidentes de trabalho com material pérfuro-cortante entre trabalhadores de enfermagem. Revista Latino-americana de Enfermagem, 10 (2002), 571-577.

[26] S.M. Medeiros, L.M. Ribeiro and V.S. Veras, Condições de trabalho e enfermagem: a transversalidade do sofrimento no cotidiano. Revista Eletrônica de Enfermagem, 8 (2006) 233240.

[27]D.P. Mendes, Donos do poder? Uma análise da atividade pericial no contexto da previdência social brasilera: limites e conflitos frente à caracterização do adoecimento em LER/DORT. Tese (Mestrado em Ciências em Engenharia de Produção) - DEP, Universidade Federal de Minas Gerais, Minas Gerais, 2006.

[28]D. Mendes, A. Silva, C. Barbosa, J. Lima, M. Oliveira and V. Matos, Um olhar sobre a atividade de trabalho de auxiliares e técnicos de enfermagem de uma instituição psiquiátrica: em busca de transformações. Anais do XV Congresso Brasileiro de Ergonomia, Porto Seguro, Bahia, 2008.

[29] V.L. Navarro, Saúde do trabalhador no SUS: aprender como o passado, trabalhar o presente, construir o futuro. Cad. Saúde Pública, 22 (2006), 2450-2452.

[30] J. Pagliari, N. Colle and C. Vieira, Sofrimento psíquico da equipe de enfermagem na assistência à criança hospitalizada. Revista Eletrônica de Enfermagem, 10 (2008), 63-76.

[31]R. J. Reis, Fatores relacionados ao absenteísmo por doença em profissionais de enfermagem. Revista de Saúde Pública, 2003; 37(5): 616-23.

[32] Y. Schwartz, Os ingredientes da competência. Um exercício necessário para uma questão insolúvel. Educação \& Sociedade, 19 (1998).

[33] Y. Schwartz, Trabalho e uso de si. Revista Proposições, 11 (2000) 34-50.

[34] Y. Schwartz, Trabalho e gestão: níveis, critérios, instâncias. $D P \& A,(2001), .23-33$. 